\title{
Export Competition Between Centrally Planned Economies and Korea
}

\author{
Josef C. Brada and Younglin Woo* \\ Arizona State University
}

\section{Abstract}

A key issue for the economies of Eastern European now undertaking the transition to capitalism is their ability to redirect their industrial exports toward the developed market economies. Previous studies of their competitiveness on these markets against goods from the Newly Industrializing Countries (NICs) tended to suggest that East European goods were not competitive. This paper compares the competitiveness of East Europe and Korea on major developed country markets. We find that competitiveness has a strong regional component which, when factored into export performance, suggests that East European manufacturers may be more competitive than previously believed.

\section{Introduction}

The collapse of the communist regimes in East Europe and in the Soviet Union has forced the smaller countries of East Europe to attempt to reorient their trade toward the West. In part this reorientation is imposed on them by the sharp decline of their exports to the former USSR, as its economy has collapsed and in part it is due to the abandonment of the CMEA mecha-

* Department of Economics, Arizona State University, Tempe, AZ 85287-3806, U.S.A.; The authors are indebted to an anonymous referee for helpful comments. Brada is indebted to the American Council of Learned Societies, the Fellowship Program of the Bundesinstitut für ostwissenschaftliche und internationale Studien and Radio Free Europe/Radio Liberty for support during the writing of this paper. 
nism, which has lowered the volume of intra-regional trade as well. At the same time, the economic failures of the communist model of economic development and the economic requirements of the transition to capitalism require greater reliance on the West as a source of technology, know-how and capital.

The ability of the reforming countries to reorient their trade toward the West, and particularly toward Western Europe, which is the major market for their exports, will depend to a large extent on their ability to find markets for both their traditional exports to the West as well as for commodities that were formerly exported to the USSR. ${ }^{1}$ This will be a formidable task, not only because many of these goods face trade barriers in the West, but also, and more important, because East European exports to Western Europe will face intense competition from newly industrializing countries (NICs). Indeed, in his seminal paper, Poznanski [1982] showed that, in the early 1970s, the market shares of East European exports to OECD countries were eroded by the increased competition of exports from NICs. If this trend continued into the $1980 \mathrm{~s}$, as Table 1 suggests it did, then it would be evident that the prospects for the easy reintegration of East Europe into the world economy would be severely limited.

As the data in Table 1 show, the NICs were able to expand their share of the OECD market in both the 1970s and in the 1980s while East Europe's share declined in the 1970 s and increased only modestly in the 1980 s. Moreover, the bulk of East Europe's increased market share in the West was due to the higher prices achieved by the USSR for its energy exports. In the area of manufactures, East Europe's share of the OECD market declined. The divergence between the export performance of the NICs and of East Europe is particularly noteworthy in manufactured goods, machinery and transportation equipment and miscellaneous manufactures, where the NICs were able to achieve dramatic gains in market share while East Europe became an increasingly marginal supplier.

This pattern of East European-NIC competitiveness is particularly striking in that both the industrial policies of the communist regimes and those of the NICs, and among those most strongly those of the Asian "develop-

1. For some estimates of the volume of these shifts, see Brada [1991]. 
Table 1

Shares of East Europe ${ }^{\mathrm{a}}$ and NICs ${ }^{\mathrm{b}}$ in OECD Imports by SITC Category

\begin{tabular}{|c|l|r|r|r|r|}
\hline \multirow{2}{*}{ Commodity } & \multirow{2}{*}{ Exporter } & \multicolumn{4}{|c|}{ Market Shares (\%) in Year: } \\
\cline { 2 - 6 } & & 1970 & 1980 & 1985 & 1987 \\
\hline \multirow{2}{*}{$\begin{array}{c}\text { Total Exports } \\
\text { (SITC 0-8) }\end{array}$} & $\mathrm{EE}$ & 1.5 & 1.3 & 2.7 & 2.3 \\
\cline { 2 - 6 } & NICs & 4.2 & 5.7 & 8.9 & 9.2 \\
\hline \multirow{2}{*}{$\begin{array}{c}\text { All Manufactures } \\
\text { (SITC 5-8) }\end{array}$} & $\mathrm{EE}$ & 1.2 & 1.4 & 1.3 & 1.2 \\
\cline { 2 - 6 } & $\mathrm{NICs}$ & 2.8 & 6.2 & 9.4 & 10.1 \\
\hline \multirow{2}{*}{$\begin{array}{c}\text { Chemicals } \\
\text { (SITC 5) }\end{array}$} & $\mathrm{EE}$ & 1.5 & 1.4 & $\mathbf{7}$ & 2.1 \\
\cline { 2 - 6 } & $\mathrm{NICs}$ & 0.9 & 1.7 & 2.9 & 2.4 \\
\hline \multirow{2}{*}{$\begin{array}{c}\text { Manufactured } \\
\text { Goods (SITC 6) }\end{array}$} & $\mathrm{EE}$ & 1.6 & 1.6 & 2.1 & 2.2 \\
\cline { 2 - 6 } & $\mathrm{NICs}$ & 2.1 & 4.7 & 7.3 & 7.1 \\
\hline $\begin{array}{c}\text { Machines \& Transport } \\
\text { Equipment } \\
\text { (SITC 7) }\end{array}$ & $\mathrm{EE}$ & 0.6 & 0.8 & 0.5 & 0.5 \\
\cline { 2 - 6 } & $\mathrm{NICs}$ & 1.2 & 4.2 & 7.3 & 8.6 \\
\hline $\begin{array}{c}\text { Miscellaneous } \\
\text { Manufactures } \\
\text { (SITC 8) }\end{array}$ & $\mathrm{EE}$ & 1.8 & 2.1 & 1.5 & 1.5 \\
\cline { 2 - 6 } & $\mathrm{NICs}$ & 10.8 & 17.3 & 22.5 & 22.0 \\
\hline
\end{tabular}

Note: a. Bulgaria, Czechoslovakia, GDR, Hungary, Poland, Rumania, USSR.

b. Argentina, Brazil, Hong Kong, South Korea, Mexico, Singapore, Taiwan. Source: OECD, Trade by Commodities, (OECD, Paris; various years).

mental states," emphasized similar sectors. Moreover, the developmental states of Asia employed similar "statist" methods to promote the development of these priority sectors. Among the techniques they employed were state ownership and guidance of priority enterprises, state controls over foreign trade and investment and the channeling of scarce resources toward priority sectors and a form of indicative planning of the economy. ${ }^{2}$ The effects on trade performance of such policies in the NIC developmental states were evidently very different from those found in the East European

2. Brada [1988] surveys East European industrial policies. For industrial policy in South Korea, the NIC on which this paper concentrates, see Ohno and Imaoka [1987] and Lee and Blumenthal [1985]. 
countries and represented a striking difference between the two systems.

In this paper, we seek to analyze the competition on OECD markets between East Europe and South Korea, an NIC that has pursued development through the promotion of sectors that were also extensively developed by East European countries. Our analysis expands previous work by employing an explicit model of competitiveness between South Korea and the East European countries. The use of an explicit model of export market shares enables us to shed light on the role of price and non-price factors in determining the role of market shares and also to show more clearly the differences in competitiveness of the rival exporters in individual OECD country markets and by commodity. In the following section, we set out the model of export market shares employed in this paper. In Section III we explain how this model was estimated and discuss our results. Section IV discusses the broader implications of our findings for the reintegration of Eastern Europe into the world economy.

\section{A Model of Export-Market Shares}

The model used to investigate comparative export performance between Korea and East Europe in Western markets is as follows:

$$
\begin{aligned}
\left(S_{1}\right)_{c, r, y} & =\left(a+\sum_{c} \alpha_{c} D_{c}+\sum_{r} \gamma_{r} D_{r}+\sum_{y} \beta_{y} D_{y}\right) \\
& +\left(b+\sum_{c} \lambda_{c} D_{c}+\sum_{r} \theta_{r} D_{r}+\sum_{y} \delta_{y} D_{y}\right) \ln \left(P_{1} / P_{2}\right)_{c, r, y}+U_{c, r}
\end{aligned}
$$

where

$S_{1} \quad=$ quantity of country 1 exports/(quantity of country 1 exports + quantity of country 2 exports);

$c, r, y=$ designation of a commodity group, importing region, and year, respectively;

$D_{c}, D_{r}, D_{y}=$ dummy variable for commodity group c, importing region $r$ and year $y$, respectively;

$P_{1}, P_{2} \quad=$ export prices of countries 1 and 2 , respectively. 
This formulation expresses country 1's share of combined country 1-country 2 exports of commodity $c$ to region $r$ as a function of the relative export price of the commodity in that region and year. ${ }^{3}$ Note that commodity, region$\mathrm{al}$ and time characteristics are represented by dummy variables in both the intercept and slope. This allows the intercept and slope to vary from commodity to commodity, importing region to importing region, and year to year. A value of one or zero is given to the commodity dummy, $D_{c}$, in the intercept depending on whether the particular price and quantity observation comes from commodity $c$ or not; the same is true for particular region $r$ and year $y$. In a similar manner the dummy variables in the slope take on a value of relative price or zero. In estimating the model, the coefficients $\alpha_{c}, \gamma_{r} \beta_{y}, \lambda_{c}, \theta_{r}$ and $\delta_{y}$ are constrained so that each of their respective sums equals zero.

The intercept coefficients indicate country 1's export market share at equal prices; this follows since $\ln _{n}\left(P_{1} / P_{2}\right)_{c, r, y}$ is zero when the export prices of the two exporting countries are equal. The mean value of this intercept, at equal prices, is $a$. It reflects the average non-price preference by importers for exports of country 1 and differing supply conditions in the two exporting countries. The additional intercept terms reveal differences in country 1's equal-price market share among commodities, regions, and years. Consider the first set of intercept coefficients, the $\alpha_{c}$ s. Each coefficient determines whether, at equal prices, the market share for a particular commodity in all regions and years differs from the average market share, $a$, for all commodities. Variation in the $\alpha_{c} s$ may arise from factors such as product quality differences, commercial policy restrictions on exporters that differ from commodity to commodity, and supply conditions in the exporting countries. The regional coefficients in the intercepts, $\gamma_{r} s$, reveal the extent to which the equal-price market share varies with importing country, reflecting particular import demand characteristics and differences in exporter policies toward various importers and vice versa. The third group of intercept coefficients, $\beta_{y} s$,

3. This formulation follows from a general specification of the demand curve for each country's export as depending on the prices of other exporters' goods, domestic substitutes and incomes. If the elasticities with respect to third country and domestic suppliers' prices are the same for country 1 and 2 , then these prices drop out of the market share equation. See Ginsburg [1969], Ginsburg and Stern [1965] and Richardson [1973] for the development of the model. 
indicate shifts in the equal-price share over time associated with changes in preferences or commercial policies of importers and variations in economic conditions andpolicies of the exporting countries.

The slope coefficients indicate the responsiveness of market shares to changes in relative export prices. The average slope for all commodities, regions, and years is $\beta$. The commodity slope coefficients, $\lambda_{c} s$, measure the difference between the average slope of commodity $c$ and the average slope for all commodities. Similarly, the $\theta_{r} s$ determine regional differences in the influence of relative prices on market shares while the $\delta_{r} s$ reveal variation in slopes among years.

\section{Results}

Separate regressions based on Equation 1 were estimated for Korea versus seven East European countries: the Soviet Union, Romania, Yugoslavia, Hungary, Czechoslovakia, the GDR and Poland. The selected importing regions were 18 of the 23 OECD member countries. Four OECD member countries, Canada, Iceland, Portugal and Turkey, were excluded since they reported very few commodities that both exporting countries exported in a given year. Yugoslavia was also excluded since it was included among the exporting countries. In addition, as West Germany did not report any imports from the former East Germany, this data was not available for the Korea-East Germany regression.

Data for these regressions were obtained from annual import statistics published by OECD. This source lists both the quantity and value of imports of OECD member countries by type of commodity and country of origin. For each regression, observations were obtained for the years 1978, 1980,1981 , and 1982 . We selected the most frequently exported commodities, in terms of both years and regions. The commodities thus selected were exported to at least 8 of 18 importing regions in at least 2 of 4 years observed. ${ }^{4}$ Observations were included for any pair of exporting countries only if both of these countries exported the commodity to a given region in

4. Each regression consists of a maximum of $C \times R \times Y=1,440$ observations on $2(I+C+R+Y)=86$ independent variables where $C, R$ and $Y$ represent the total number of commodities (20), importing region (18), and years (4) included in the model. 
a given year. This procedure eliminated observation where an exporter's market share was zero or 100 percent. Hence, commodities were chosen for inclusion in the regressions only if both exporters exported them to a sufficient number of the 18 importing regions over a sufficient span of time to make estimation meaningful. As a result of this selection procedure, a total of 53 commodities disaggregated at the 5-digit Standard International Trade Classification (SITC)were utilized. The overlap between the commodity structure of Korea and East European exports was such that of these 53 commodities at most 20 and at least 17 entered any individual regression.

Before presenting the results, we would like to point out that the data requires the use of average unit values in place of prices. The primary difficulty in the use of average unit values is that, unless the goods within each commodity classification are quite homogeneous, changes in the commodity composition within a classification make intertemporal or cross-country comparisons problematic. In order to overcome this difficulty, we have utilized the narrowest commodity classifications possible. In addition, there is reason to expect that the commodity composition of individual classifications is quite homogeneous in the case of East European exports. This is due to the fact that, under the system of state trading employed in East Europe, only a few enterprises in a given branch of industry produce for export. Consequently, the variations in commodity quality and type within each classification is much smaller than it would be in trade among market economies when a large number of producers may be exporting. Thus, use of unit values probably does not create any serious bias within the context of this study.

Table 2 presents estimate of the average equal-price market share for the Korea-East European countries regressions. In addition to the tests of significance of individual coefficients reported in Table 2, significance tests were performed for each group of coefficients. This was done since the coefficients within a particular category - importing region, time, or commodity - were estimated under the constraint that for each category, the coefficients sums to zero. Consequently, it can be argued that their statistical significance should be considered jointly rather than individually. These tests indicated that each group of intercept coefficients, years, regions, and commodities, was significant at the 0.01 level.

Line 1 of Table 2 presents an estimate of the average equal-price market 
Table 2

Estimates of the Average-, Regional-, and Annual-Nonprice Coefficients

\begin{tabular}{|c|c|c|c|c|c|c|c|c|}
\hline \multicolumn{2}{|c|}{$\begin{array}{l}\text { Independent } \\
\text { variable }\end{array}$} & K-SOV & K-ROM & K-YUG & K.HUN & K-CZE & K-GER & K-POL \\
\hline \multicolumn{2}{|c|}{$\begin{array}{l}\text { Average equal price } \\
\text { market share (a) }\end{array}$} & $0.713^{\mathrm{a}}$ & $0.587^{\mathrm{a}}$ & $0.599^{\mathrm{a}}$ & $0.608^{\mathrm{a}}$ & $0.716^{\mathrm{a}}$ & $0.594^{\mathrm{a}}$ & $0.698^{\mathrm{a}}$ \\
\hline \multirow{18}{*}{$\begin{array}{l}\text { Importing } \\
\text { region }(\gamma)\end{array}$} & U.S. ${ }^{d}$ & 0.254 & 0.197 & 0.288 & 0.215 & 0.282 & 0.267 & 0.232 \\
\hline & Japan & $0.157^{\mathrm{a}}$ & $0.320^{b}$ & $0.308^{\mathrm{a}}$ & $0.344^{\mathrm{a}}$ & $0.262^{\mathrm{a}}$ & $0.354^{\mathrm{a}}$ & $0.260^{\mathrm{a}}$ \\
\hline & Australia & 0.237 & 0.051 & $0.247^{\mathrm{a}}$ & 0.023 & $0.104^{c}$ & $0.254^{\mathrm{a}}$ & 0.107 \\
\hline & Austria & -0.065 & -0.013 & $-0.244^{\mathrm{a}}$ & $-0.202^{\mathrm{a}}$ & $-0.084^{b}$ & $-0.136^{a}$ & -0.067 \\
\hline & Belgium-Luxembourg & $-0.177^{a}$ & $-0.020^{c}$ & -0.122 & $-0.085^{b}$ & $-0.081^{b}$ & $-0.065^{b}$ & $-0.067^{c}$ \\
\hline & Denmark & $-0.156^{a}$ & -0.012 & -0.085 & $-0.165^{a}$ & $-0.070^{b}$ & $-0.301^{a}$ & $0.152^{\mathrm{a}}$ \\
\hline & Finland & $-0.168^{a}$ & $-0.143^{a}$ & -0.051 & $-0.161^{a}$ & $-0.129^{\mathrm{a}}$ & $-0.231^{a}$ & $0.121^{\mathrm{a}}$ \\
\hline & France & 0.059 & $-0.171^{a}$ & $-0.104^{a}$ & 0.018 & 0.041 & 0.051 & 0.015 \\
\hline & Germany(Fed.Rep) & -0.025 & -0.104 & $-0.126^{\mathrm{a}}$ & $-0.057^{c}$ & $0.102^{\mathrm{a}}$ & & 0.036 \\
\hline & Greece & $-0.167^{b}$ & $-0.155^{c}$ & 0.044 & 0.035 & $-0.105^{b}$ & $-0.120^{2}$ & -0.091 \\
\hline & Ireland & 0.037 & -0.003 & $0.129^{a}$ & $0.152^{c}$ & $-0.075^{c}$ & 0.032 & $-0.101^{b}$ \\
\hline & Italy & 0.010 & $-0.147^{a}$ & $-0.200^{\mathrm{a}}$ & -0.028 & 0.061 & 0.098 & $-0.038^{a}$ \\
\hline & Netherlands & 0.033 & 0.065 & 0.035 & -0.009 & 0.019 & $-0.057^{c}$ & $0.063^{\mathrm{b}}$ \\
\hline & Norway & $-0.104^{b}$ & $-0.113^{b}$ & 0.034 & -0.050 & $-0.149^{a}$ & $0.171^{a}$ & $-0.089^{b}$ \\
\hline & Spain & 0.011 & -0.042 & -0.086 & 0.077 & $-0.118^{a}$ & -0.084 & -0.004 \\
\hline & Sweden & -0.023 & 0.058 & 0.003 & -0.021 & -0.025 & -0.051 & -0.014 \\
\hline & Switzerland & 0.103 & $0.145^{b}$ & $-0.135^{\mathrm{a}}$ & $-0.134^{\mathrm{a}}$ & $-0.087^{a}$ & $-0.155^{\mathrm{a}}$ & -0.006 \\
\hline & U.K. & -0.017 & $0.086^{\mathrm{b}}$ & $0.062^{b}$ & 0.048 & $0.054^{\mathrm{c}}$ & $0.097^{\mathrm{a}}$ & 0.037 \\
\hline \multirow{4}{*}{$\operatorname{Year}(\beta)$} & $1978^{\mathrm{d}}$ & -0.032 & 0.001 & -0.046 & -0.025 & -0.042 & -0.051 & -0.069 \\
\hline & 1980 & 0.002 & -0.004 & 0.022 & 0.008 & 0.005 & 0.012 & -0.019 \\
\hline & 1981 & 0.006 & -0.001 & $0.026^{c}$ & 0.002 & 0.022 & $0.027^{c}$ & $0.031^{b}$ \\
\hline & 1982 & 0.024 & 0.004 & -0.002 & 0.015 & 0.015 & 0.012 & $0.057^{a}$ \\
\hline
\end{tabular}

Note: a,b,c indicate significance from zero at the $.01, .05$, and .10 levels.

d. Significance level not computed due to estimation constraint.

share for Korea in western markets, and subsequent lines represent the deviation from this average value by importer and year as measured by the regional and time coefficients respectively. Thus, for example, we observe that the equal-price market share of Korea ranges from 58.7 percent of 
Korean-Romanian exports to 71.6 percent of Korean-Czechoslovak exports to western markets. These equal-price market shares primarily reflect the economic size and the ratio of exports to GNP in the exporting countries. In addition, differences in the policies of western countries towards Korea and its socialist competitors also play an important role in determining the volume of exports directed to western markets. While these results provide an overview of the relative export volumes of these countries, it is the examination of deviations in the equal-price market shares from the average that is the most important in explaining the impact of different policies and political conditions on these export partners.

The regional intercept coefficients reported in Table 2 measure the degree to which the equal-price market share in region $r$ deviates from the average equal-price market share over all importing regions. Thus, using the Korean-Soviet regression results as an example, Korea's equal-price market share in the United States was 96.7 percent, that is $71.3+\gamma_{u s}$, while in Japan it was 87.0 percent, $71.3+\gamma_{j a p}$. The regional coefficients show very clearly the different geographical pattern of exports of Korea and East Europe. Korea's export shares are above average in the United States, a market that has been the target of Korea's industrial policy, and in Japan and Australia, markets where Korea would be expected to predominate because of its proximity. At the same time, proximity alone cannot explain the pattern of regional advantage since Korea's export shares are also above average in some Western European countries.

The mixed results for Western Europe reflect the fact that there was a wide variety of non-tariff restrictions imposed on East European exports while relatively fewer restrictions were imposed on Korean goods, both in Western Europe and especially in the US and Japan. For example, the United States had a number of legislative acts that created hindrances for goods imported from East Europe.

Nevertheless, tariff discriminations, such as MFN (Most Favored Nation) treatment does not seem to be an important factor in explaining the superior performance of Korea in the United States. The United States has granted MFN status to Korea and to 4 of 7 East European countries, Poland, Romania, Hungary and Yugoslavia. In all regressions, Korea performed much better than any East European country in the United States. 
The best performance among East European countries in the U.S. was observed in the case of Romania, whose share was 41.3 percent of the average equal-price market share and 21.6 percent of equal-price market in the United States. The most compelling explanation for Romania's performance is due to greater sales effort on the part of the Romanian foreign trade corporations. Romania had sought to expand its trade with the West, especially with the United States in the 1960s and 1970s. Improvements in relations between the two countries were exemplified by commercial agreements signed in the mid-1960s as well as by greater sales effort on the part of Romania. In addition, Romania was granted MFN status in 1975, although this was subsequently withdrawn due to human-rights abuses by the Ceasescu regime. One other possible explanation of Romanian performance may be the choice of commodities in our regressions. The commodities selected for the Korean-Romanian regression consisted mostly of miscellaneous manufactures (SITC-8), which made up 13 of 18 commodities in this sample. This indicates that Korea competed with Romania more in light manufacturing industries such as footwear and garments than it did with other East European countries. Since the early 1970 s, Korea had shifted its industrial policy from light industries to capital- and technology-intensive industries. Thus, Korea was not as competitive in the former industries as it had been in the 1960 s, giving the appearance of Romania's better performance vis- $a$ vis other East European countries.

The Korea-Soviet Union regression suggests that political conditions also influenced the export performance of the Soviet Union. After the second oil shock in 1979, Korea suffered a severe economic recession that was due to the rise in energy prices, to political disruption following President Park's death, to a poor harvest in 1980 and to poor economic policies (Kuznets [1982, 1990]). The oil shock hurt all industries of Korea, including export industries. In contrast, the Soviet Union was one of the largest oil producing countries in the world. Hence, it took advantage of the oil shock and should have been able to show better export performance than non-oil producing countries such as Korea and other East European countries during this period. However, our results indicate that the Soviet Union did not improve its performance after the oil shock as indicated by the non-significant positive year coefficients in the 1980 s. This unexpected result is attributable to politi- 
cal conditions for East-West trade in this period. The United States reaction to the Soviet military intervention in Afghanistan at the end of 1979 was to impose extensive economic sanctions, and the West European countries and Japan followed the United States' reactions. Moreover, the new American administration, which had been in office since January, 1981, had embarked on a much firmer course and this, in turn, reduced exports of the Soviet Union at that time.

The Korea-Poland regression regression results show Korea's equal-price market share in 1978 was 62.9 percent, while in 1982 , it increased to 75.7 percent. This poor performance of Poland in the early 1980 s is due to the economic crisis that Poland faced at that time.

In addition to its better performance in its target markets, the United States, Japan and Australia, Korea had market shares that were above average in the large West European countries and below average shares in the smaller ones. Since there are considerable costs to breaking into new markets, it is not surprising that, given the distance between Europe and Korea, Korean exporters have chosen to focus on the largest national markets such as Germany, France and Italy. The East European countries, being closer to European markets, are able to penetrate the smaller national markets since the costs of travel, communications and transportation are less. These results do suggest that, despite geographical disadvantages, NICs appear able to compete with East European exporters on European markets if they find markets of sufficient size.

The year intercept coefficients reported in Table 2 measure the amount by which the equal-price market share in year $y$ deviates from the average equal-price market share over all years. ${ }^{5}$ The year coefficients show few significant deviations from the average although they do indicate positive trend in the equal-price market share of Korea in the 1980s. This positive trend indicates that Korea has increased its competitive edge over East European countries over time. Most regressions show a positive trend of year coeffi-

5. As a group, these year coefficients are statistically significant at the 0.01 level in all regressions. Recall that the coefficients within a particular category - time, importing region or commodity - are estimated under the constraint that for each category, the coefficients sum to zero; consequently, it is meaningful to consider their significance jointly as well as individually. 
Table 3

Estimates of the Average, Regional and Annual Elasticities of Substitution

\begin{tabular}{|c|c|c|c|c|c|c|c|c|}
\hline \multicolumn{2}{|c|}{$\begin{array}{l}\text { Independent } \\
\text { variable }\end{array}$} & K.SOV & K-ROM & K-YUG & K-HUN & K-CZE & K-GER & K.POL \\
\hline \multicolumn{2}{|c|}{ Average elasticity } & -0.199 & -0.015 & -0.110 & -0.129 & -0.106 & -0.129 & -0.165 \\
\hline \multirow{18}{*}{$\begin{array}{l}\text { Importing } \\
\text { region }(\theta)\end{array}$} & U.S. & 0.191 & 0.095 & 0.214 & 0.011 & 0.282 & -0.046 & 0.230 \\
\hline & Japan & 0.199 & 0.215 & 0.206 & 0.114 & 0.183 & 0.063 & 0.133 \\
\hline & Australia & -0.161 & 0.021 & 0.036 & 0.183 & 0.118 & -0.116 & -0.043 \\
\hline & Austria & -0.016 & -0.024 & -0.092 & -0.032 & -0.076 & 0.029 & -0.068 \\
\hline & Belgium-Luxembourg & 0.112 & -0.054 & -0.046 & -0.002 & 0.052 & -0.003 & 0.052 \\
\hline & Denmark & 0.059 & -0.168 & 0.016 & 0.021 & -0.097 & 0.048 & -0.014 \\
\hline & Finland & -0.152 & -0.120 & -0.077 & 0.023 & -0.107 & -0.001 & 0.034 \\
\hline & France & -0.027 & -0.029 & -0.067 & -0.037 & 0.046 & -0.027 & -0.002 \\
\hline & Germany (Fed.Rep) & 0.116 & 0.009 & -0.097 & -0.018 & -0.005 & & -0.045 \\
\hline & Greece & -0.167 & -0.078 & 0.059 & -0.077 & -0.166 & -0.002 & -0.083 \\
\hline & Ireland & -0.009 & 0.018 & -0.071 & -0.025 & -0.059 & 0.051 & 0.035 \\
\hline & Italy & -0.084 & 0.085 & -0.080 & 0.027 & -0.012 & 0.028 & 0.049 \\
\hline & Netherlands & 0.053 & -0.001 & 0.038 & -0.102 & -0.127 & -0.075 & -0.078 \\
\hline & Norway & 0.013 & 0.059 & -0.024 & 0.014 & 0.051 & 0.033 & -0.018 \\
\hline & Spain & -0.198 & 0.132 & -0.104 & -0.014 & 0.073 & -0.015 & 0.092 \\
\hline & Sweden & -0.021 & -0.046 & 0.074 & -0.052 & -0.003 & -0.012 & -0.077 \\
\hline & Switzerland & 0.010 & -0.106 & 0.105 & -0.057 & -0.029 & 0.065 & -0.147 \\
\hline & U.K. & 0.083 & -0.062 & -0.089 & 0.021 & 0.070 & -0.019 & -0.048 \\
\hline \multirow{4}{*}{ Year $(\delta)$} & 1978 & -0.009 & -0.037 & -0.002 & -0.005 & -0.004 & 0.002 & 0.001 \\
\hline & 1980 & -0.001 & 0.008 & 0.001 & 0.002 & 0.014 & -0.007 & 0.013 \\
\hline & 1981 & 0.011 & 0.025 & -0.007 & -0.001 & 0.009 & 0.006 & 0.005 \\
\hline & 1982 & -0.001 & 0.004 & 0.008 & 0.004 & -0.019 & -0.001 & -0.019 \\
\hline
\end{tabular}

cients in 1980s while they were mainly negative in 1978 expect in the Romania-Korea regression. Thus, this trend shows East Europe became less competitive against Korea in western markets over the sample period.

Our results also provide information on the role of relative prices of exports on Korean and East European competitiveness in the West. Estimates of the average elasticity of substitution, over all years and regions for 
each regression are reported in the first row of Table 3. All these results show very low elasticities of substitution between Korean and East European goods. East European countries have had problems breaking into western markets. Given their limited marketing expertise and capabilities, their often deficient after-sales service and the reputedly mediocre quality of their products, they have faced and continue to face truly formidable difficulties in expanding their exports in western markets. Their only apparent means of overcoming these problems was offering generous price incentives to western importers. Such an underpricing was possible in East Europe since the system of planning tended to facilitate these uneconomic practices. East European foreign trade organizations sometimes accepted unnecessarily low prices for their goods because they had insufficient knowledge of western markets. In other cases, they quickly sold for whatever prices they could obtain when faced with the need to fulfil their export plans. As a result, the elasticity of demand for East European goods appears to be very low since price was very flexible while the quantity of exports was somewhat rigid to reflect the planned export target.

Table 4 indicates in which SITC commodity groups Korea and East Europe competed with each other in western markets. Among the 123 selected commodities in the regressions, 69 were miscellaneous manufactures (SITC 8). Manufactured goods (SITC 6) followed as the next frequently encountered SITC commodity group exported by both competitors with 48 commodities, and only one commodity in chemicals (SITC 5) was observed in the Korea-Hungary regression. This indicates that the export performance of Korea and East Europe in western markets was largely determined by competitiveness in miscellaneous and manufactured goods (SITC 6 \& 8) since more than 95 percent of the total selected commodities consisted of these two commodity groups. On the other hand, chemicals (SITC 5) and machinery and transport equipment (SITC 7) are not important commodity groups that influence export competitiveness between Korea and East Europe.

One interesting observation was that for countries such as Romania, Yugoslavia and East Germany, more than 50 percent of their selected commodity groups were miscellaneous manufactures. Coincidentally, these countries showed better average equal-price market shares than did coun- 
Table 4

Commodity Groups Classification of Each Regression

\begin{tabular}{|l|c|c|c|c|c|c|}
\hline Regression & SITC 5 & SITC 6 & SITC 7 & SITC 8 & Total & $\begin{array}{c}\text { Percent } \\
\text { (SITC 8/Total) }\end{array}$ \\
\hline K-SOV & 0 & 6 & 3 & 7 & 16 & 43.7 \\
K-ROM & 0 & 4 & 1 & 13 & 18 & 72.2 \\
K-YUG & 0 & 8 & 0 & 9 & 17 & 52.9 \\
K-HUN & 1 & 8 & 1 & 7 & 17 & 41.1 \\
K-CZE & 0 & 9 & 0 & 8 & 17 & 47.1 \\
K-GER & 0 & 7 & 0 & 13 & 20 & 65.0 \\
K-POL & 0 & 6 & 0 & 12 & 18 & 66.7 \\
\hline Total & 1 & 48 & 5 & 69 & 123 & 56.1 \\
\hline Percent & 0.8 & 39 & 4.1 & 56.1 & 100 & \\
\hline
\end{tabular}

tries such as Hungary, the Soviet Union and Czechoslovakia, whose exports were more heavily weighted toward SITC category 6 .

\section{Conclusions}

Our results show that there is a very large difference between the geographic distribution of East European exports to developing countries and those of the NIC, Korea, that we have examined. Korea's exports are heavily focused on Japan and the United States, and correspondingly less focused on Western Europe. ${ }^{6}$ This suggests that evidence such as that provided by Poznanski [1982] on the basis of imports to all OECD countries may understate the competitiveness of East European exports. If the NICs concentrated their exports on the United States market, which tended to be more open and more dynamic and which experienced a much more rapid growth of imports than did Western Europe, then their better export performance may more reflect the geographic distribution of their exports than their ability to compete with East European exports, which were directed more

6. The pattern is true for most other NICs as well. 
toward the Western European market and its weaker import dynamic.

At the same time, Korea's performance in the large Western European markets does indicate that NICs do have the ability to compete with East Europe on European markets. The fact that Korea is better able to compete in high technology and capital-intensive goods, and less competitive in sectors such as textiles and footwear does suggest some niches and possible export strategies for East Europe. However, textiles, footwear and other labor-intensive industries tend to enjoy the greatest protection in developed market economies.

\section{References}

Brada, J. [1988], "Industrial Policy in East Europe," in J.C. Brada, E.A. Hewett and T.A. Wolf (eds.), Economic Adjustment and Reform in Eastern Europe and the Soviet Union, Duke University Press, Durham; pp. 109-146.

Brada, J. [1991], "Integrating Eastern Europe and the Soviet Union into the World Economy," in R. Baldwin and J.D. Richardson (eds.), The Uruguay Round and Beyond: Problems and Prospects, National Bureau of Economic Research, Cambridge; pp. 93-125.

Ginsburg, A. [1969], American and British Regional Export Determinants, Amsterdam.

Ginsburg, A. and R. Stern [1965], "The Determination of Factors Affecting American and British Exports in the Inter-War and Post-War Periods," Oxford Economic Papers; pp. 263-278.

Kuznets, P. [1982], "The Dramatic Reversal of 1979-80: Contemporary Economic Developments in Korea," Journal of Northeast Asian Studies; pp. 71-87.

Kuznets, P. [1990], "Indicative Planning in Korea," Journal of Comparative Economics; pp. 156-176.

Lee, C.H. and J. Blumenthal [1985], "Development Strategies of Japan and the Republic of Korea; A Comparative Study," The Developing Economies; pp. 221-235.

Ohno, K. and H. Imaoka [1987], "The Experience of Dual-Industrial Growth: Korea and Taiwan," The Developing Economies; pp. 310-321. 
Poznanski, K. [1982], "Competition between Eastern Europe and Developing Countries in the Western Market for Manufactured Goods," in Joint Economic Committee, United States Congress, East European Economies in a Time of Slow Growth, Washington.

Richardson, J. [1973], "Beyond (but back to?) the Elasticity of Substitution in International Trade," European Economic Review; pp. 381-392. 